\title{
ПЕДАГОГІЧНЕ МОДЕЛЮВАННЯ ЯК ЗАСІБ ФОРМУВАННЯ МЕТОДИЧНОЇ КОМПЕТЕНТНОСТІ МАЙБУТНЬОГО ВЧИТЕЛЯ
}

\author{
Олена Ішутіна
}

кандидат педагогічних наук, доцент кафедри теорії і практики початкової освіти ДВНЗ «Донбаський державний педагогічний університет»

Слов'янськ, Україна $\frac{\text { http://orcid.org/0000-0002-7801-4205 }}{\text { olenaishutina@gmail.com }}$

\section{Слизавета Шаповалова}

студентка факультету початкової, технологічної та професійної освіти ДВНЗ «Донбаський державний педагогічний університет»

Слов'янськ, Україна

yeshapovalova@gmail.com

Анотація. У статті подано загальний аналіз педагогічного моделювання як засобу формування методичної компетентності майбутнього вчителя, розкрито деякі підходи до класифікації, представлено основні позиції застосування педагогічного моделювання в теорії та практиці професійної освіти вчителів. Доведено, що будь-яке моделювання передбачає використання абстрагування та ідеалізації (особливо це відноситься до моделювання складних педагогічних систем, поведінка яких залежить від великого числа взаємопов'язаних факторів різної природи). У педагогічному моделюванні найчастіше затребувані структурнофункціональні моделі, при проектуванні яких об'єкт розглядається як цілісна система, що включає складові частини, компоненти, елементи, підсистеми. Побудова такої моделі дозволяє отримати нову інформацію про поведінку об'єкта, виявити взаємозв'язки та закономірності, які не вдається виявити при інших способах аналізу. Студентам пропонувалось будувати моделі макро- й мікроструктури аспектних уроків та уроків зв'язного мовлення в різних класах. Моделюючи уроки мови, майбутні вчителі послуговувались засвоєними на заняттях із педагогіки, психології та лінгвометодики лінгвометодичними термінами-синонімами.

Ключові слова: вища освіта; методична компетентність; моделювання; педагогічне моделювання; учитель початкової школи.

Постановка проблеми в загальному вигляді. Нові вимоги до освіти в сучасному українському суспільстві полягають, насамперед, у підготовці людини, здатної до опанування нових професійних знань та вмінь. Такий підхід у сучасній освіті забезпечує перенесення акценту від «інформаційного енциклопедиста» до «людини-дослідника», перехід від процесу накопичення знань до процесу більш глобального - опанування способів діяльності. Це означає, що, навчаючи школярів, треба пам'ятати не лише про формування в них системи знань, але й про розвиток сукупності прийомів, умінь для досягнення цілей, спрямованих на отримання освіти впродовж життя [2]. Одним зі шляхів виконання окреслених завдань $є$ розвиток в учнів дослідницької компетентності, 
що відображено в низці таких законодавчих актів та програм, як Закон України «Про освіту», Національна доктрина розвиткові України у XXI ст., Державна програма «Учитель», Болонська декларація та ін.

Більше того, активному залученню учнів до дослідницької діяльності сприятиме й дебюрократизація школи, завдяки якій більше ніж на 1500 показників скоротилася кількість звітних документів; упроваджено низку тактичних змін у зміст середньої освіти з метою розвантаження навчального процесу для учнів та педагогів; накладено мораторій на перевірку шкіл тощо. Результатом виконання зазначених програм, законодавчих актів та заходів $\mathrm{MOH}$ України має стати створення ефективної системи освіти, яка гарантуватиме розвиток дослідницької компетентності випускника школи у зв'язку з потребами особистості, суспільства й держави.

Ефективне вирішення завдання щодо розвитку дослідницької компетентності учнів старших класів у процесі навчання фізики, на наш погляд, можливе за умови використання в навчально-виховному процесі загальноосвітнього навчального закладу педагогічного моделювання. Цей метод дослідження набув особливого статусу в психолого-педагогічних дослідженнях останніх років, пов'язаних із моделюванням понятійних, процесуальних, структурних і концептуальних характеристик та окремих аспектів навчання й виховання на загальноосвітньому та професійно орієнтованому рівнях. Отже, можемо констатувати виняткову роль моделювання в психолого-педагогічних дослідженнях.

Аналіз останніх досліджень і публікацій. Застосовували універсальний метод моделювання в сучасній науці такі вчені, як: Д. Айстраханов, Н. Вінер, Т. Гуменюк， В. Давидов， О. Дахін， Е. Нікітін， С. Павлютенков， П. Трусов, В. Штофф та ін. Аналіз багатьох публікацій з окресленого питання дозволив констатувати, що метод моделювання має базуватися на логічному й концептуальному обгрунтуванні та мінімальній кількості припущень, причому вказана кількість припущень повинна бути достатньою для формування цілісного уявлення про об'єкт дослідження. Можливостям моделювання освітніх систем приділяють дедалі більше уваги в науково-педагогічних дослідженнях, оскільки його першочергове завдання вбачають у виявленні ресурсу саморозвитку, самовдосконаленні в межах самих освітніх систем.

Проблеми, пов'язані 3 моделюванням певних процесів у навчальновиховному процесі навчальних закладів усіх типів, перебувають у полі зору багатьох науковців. Так, О. Мещанінов розробляє сучасні моделі університетської освіти в Україні, Р. Серьожникова - моделювання педагогічного процесу формування творчого педагогічного потенціалу майбутнього викладача у процесі професійної підготовки в університеті (на прикладі підготовки викладача економіки), О. Коберник - моделювання різних аспектів виховного процесу в сільській загальноосвітній школі тощо. Інші аспекти проблеми моделювання професійної діяльності спеціалістів висвітлено 
в наукових працях А. Вербицького, Л. Семушиної, А. Дахіна, В. Загвязинського, В. Корнещук та ін.

Формулювання цілей статті. Мета статті полягає у висвітленні ефективності застосування педагогічного моделювання як засобу формування методичної компетентності майбутніх учителів, зокрема лінгвометодичної компетентності майбутніх учителів початкової школи.

Результати дослідження. Загальнонаукові поняття «модель» i «моделювання» $\epsilon$ важливими i водночас складними інструментами для педагогіки. По-перше, вони потрапили в означену сферу з інших галузей знань; по-друге, як зазначає Є. Лодатко, вони мають «особливості, природа яких грунтується на нечіткості, розпливчастості педагогічних понять» [4] $\mathrm{i}$, як свідчать результати термінологічного аналізу, поняття «модель» розуміють:

1) у широкому значенні: як систему, що мисленнєво уявляється або матеріально реалізується і, відображаючи або відтворюючи об'єкт дослідження, здатна заміщати його так, що ііі вивчення дає нову інформацію про цей об'єкт;

2) у вузькому значенні: зображення певного явища за допомогою іншого, більш вивченого, яке легше зрозуміти;

3) як спрощені теорії, що дозволяють вивчати взаємозв'язки між різними індикаторами в суспільстві;

4) як схему, графік будь-якого об'єкта, процесу або явища, що використовується як його спрощена заміна.

Дані визначення дають можливість зробити такі узагальнення: системоутворювальним чинником понять «модель», «моделювання педагогічного процесу» є педагогічна реальність, яку моделюють - система, реальність, модель як образ цієї реальності - система-модель і суб'єкт моделювання (педагог) - система, що моделює. У такому розумінні моделювання в педагогічному процесі має гносеологічно-пізнавальний характер, а отримані моделі $\epsilon$ «моделями дослідження» [2, с. 51]. Однак модель у педагогічному процесі - це не тільки відображення деякого стану педагогічної реальності, а й «форма діяльності, яка передбачається, репрезентація майбутньої практики й засвоєних форм діяльності» [1, с. 11]. Інакше кажучи, модель у педагогічному процесі може бути образом не тільки теперішньої чи минулої педагогічної реальності, а й майбутньої. У такому розумінні модель несе функцію прогнозування, планування, цілеутворювання майбутньої діяльності педагога.

Так, опанування курсу «Методика навчання української мови в початковій школі» 3 обов'язковістю включає в себе практичні заняття, на яких майбутні вчителі не лише закріплюють і поглиблюють знання 3 курсу, але й відпрацьовують основні складники лінгвометодичної компетентності, задля чого виконують практичні завдання на розробку окремих складників уроку мови й мовлення, моделювання власних фрагментів та цілих уроків мови й розвитку

Професіоналізм педагога: теоретичні й методичні аспекти. - Вип. 7. - Слов’янськ, 2018. 
Педагогічне моделювання як засіб формування методичної компетентності вчителя

мовлення, виховних заходів й позакласних занять із рідної мови й розвитку мовлення, демонстрацію їх проведення в аудиторних умовах тощо.

Кожен з указаних видів діяльності є показником сформованості певного компонента лінгвометодичної компетентності майбутнього вчителя початкової школи чи цього особистісного феномену в загальному вигляді і відповідно може розглядатися як специфічний метод контролю - моделювання лінгвометодичної діяльності, що дозволяє викладачеві оцінити рівень лінгвометодичної грамотності студентів, їхньої здатності творчо використовувати знання для вирішення конкретних методичних завдань, володіння основними лінгвометодичними вміннями.

Специфіка лабораторно-практичних занять 3 методики навчання української мови в реалізації методики формування професійної компетентності майбутніх учителів початкової школи полягала в тому, щоб озброїти студентів уміннями застосовувати на практиці теоретичні знання, навчити переймати досвід учителів ЗОШ, самостійно планувати навчальний матеріал, моделювати уроки різних типів.

Із цією метою студентам пропонувалось будувати моделі макро- й мікроструктури аспектних уроків та уроків зв'язного мовлення в різних класах. Від студентів вимагалось чітко розрізняти ці поняття, ураховувати нові підходи до технології уроку, вимоги до особистості вчителя, до його вмінь діагностувати навчальні цілі, передбачати результати спільної діяльності тощо.

Так, наприклад, студентам було запропоновано побудувати моделі аспектних уроків української мови під час вивчення теми «Особливості структури уроку мови».

Bapiaнm 1. Модель структури уроку вивчення нового матеріалу.

Bapiaнm 2. Модель структури уроку формування вмінь і навичок.

Bapiaнm 3. Модель структури уроку повторення.

Bapiaнm 4. Модель структури уроку вивчення нового матеріалу.

Bapiaнm 5. Модель структури уроку контрольної роботи.

Bapiaнm 6. Модель структури уроку аналізу контрольної роботи.

Bapiaнm 7. Модель структури уроку навчального переказу.

Bapiaнm 8. Модель структури уроку контрольного переказу.

Bapiaнm 9. Модель структури уроку аналізу контрольного переказу.

Bapiaнm 10. Модель структури уроку навчального твору.

Bapiaнm 11. Модель структури уроку контрольного твору.

Bapiaнm 12. Модель структури уроку аудіювання і читання.

Моделювання аспектних уроків та уроків розвитку зв'язного мовлення передбачало комбінування різних етапів у певній послідовності відповідно до логіки предмета та дидактичної мети. Завдання такого типу були спрямовані на формування і розвиток проективних умінь студентів.

Моделюючи уроки мови, майбутні вчителі послуговувались засвоєними на заняттях із педагогіки, психології та лінгвометодики, лінгвометодичними термінами-синонімами, як наприклад: підготовка до сприймання нового 
Педагогічне моделювання як засіб формування методичної компетентності вчителя

матеріалу - мотивація навчальної діяльності; оголошення теми і мети актуалізація опорних знань учнів; закріплення знань, умінь і навичок - набуття первинного досвіду учнів на основі вивченого матеріалу; оголошення домашнього завдання - інструктаж щодо виконання домашнього завдання тощо.

Надалі завдання було ускладнено, і студентам пропонувалося змоделювати два паралельні варіанти одного типу уроку - традиційний і нестандартний.

Завдання 1

Побудувати модель структури традиційного уроку вивчення нового матеріалу й уроку-гри.

Завдання 2

Побудувати модель структури уроку формування вмінь й навичок учнів і уроку-подорожі.

Завдання 3

Побудувати модель структури уроку узагальнення й систематизації знань, умінь і навичок й уроку-взаємонавчання.

\section{Завдання 4}

Побудувати модель структури традиційного уроку написання контрольної роботи й уроку-змагання.

\section{Завдання 5}

Побудувати модель структури традиційного уроку розвитку зв'язного мовлення й уроку-вистави.

Щодо моделювання уроків на рівні мікроструктури, то студентам пропонувались завдання на моделювання окремих етапів 3 конкретизацією застосування методів, прийомів і засобів навчання, можливою реалізацією загальнодидактичних і лінгвометодичних принципів навчання. Наприклад:

Варіант 1.

Модель етапу вивчення нового матеріалу уроку вивчення нового матеріалу.

\section{Варіант 2.}

Модель етапу формування умінь і навичок учнів уроку закріплення знань $\mathrm{i}$ формування вмінь і навичок.

Варіант 3.

Модель етапу підготовчих вправ до написання творчого переказу.

Варіант 4.

Модель етапу лінгвістичної розминки нетрадиційного уроку-змагання.

Наводимо варіанти завдань, пропоновані студентам експериментальних груп.

Завдання 1.

1. Скласти план-конспект уроку закріплення знань і формування вмінь $\mathrm{i}$ навичок «Будова слова» або «Словотвір» (4 клас).

2. Підготувати електронну наочність до розділу «Словотвір».

Завдання 2. 
1. Підготувати методичну розробку одного з етапів уроку вивчення нового матеріалу з теми «Словосполучення»:

a) підготовка до сприймання нового матеріалу

б) вивчення нового матеріалу;

в) закріплення виучуваного матеріалу.

2. Змоделювати схему, серію малюнків до теми «Словосполучення», комплект карток для індивідуальної роботи, серію тестових завдань «Словосполучення» (за вибором студентів).

Матеріали для проектування й конструювання основних етапів уроку вивчення нового матеріалу

I. Запитання для бесіди з учнями:

1. Що ми називаємо словосполученням?

2. Які сполуки слів не належать до словосполучень? Наведіть приклади.

3. Як визначити головне і залежне слово в словосполученні?

4. Якими частинами мови можуть виступати головні слова?

5. Які $\epsilon$ типи синтаксичного зв'язку слів у словосполученнях? Теоретичне положення проілюструйте прикладами. вибір.

II. Визначте типи зв’язку слів у словосполученнях. Аргументуйте свій

Читання вголос, шапка набакир, непохитна мужність, сьогодні вдень, зовсім поруч, рідний погляд, молодіжний фестиваль, пісня про щастя, потрібний людям, єдина мета, радісно дітям, готуватися до зустрічі

Доберіть антоніми до виділених слів і складіть із ними словосполучення.

III. Поясніть лексичне значення запропонованих слів:

жовтогарячий, поспішати, Чумацький Шлях, батьківщина, Батьківщина, прибережний, несподівано.

IV. Прочитайте текст. Випишіть із нього словосполучення, розподіливши ïx за способом вираження головного слова в три колонки: 1 - іменні; 2 дієслівні; 3 - прислівникові.

«Хата без рушника, що сім'я без дітей»,- говорили в народі. Майже в кожній, навіть найбіднішій оселі, завжди на видному місці висіло декілька видів рушників. До речі, удвічі більше було господарських. «Утирач» використовували для рук і обличчя, «стирок» для посуду, стола і лав, «божник» - для облямування дорогих ікон. Окремо зберігалися ритуальні рушники. Плечові призначалися для сватів, весільні - для різноманітних весільних обрядів. Дуже гарно, коли при оформленні шлюбу молоді «ставали на рушник». (В. Супруненко)

V. Прочитайте подані словосполучення. Запишіть їx, виправляючи помилки. Утворіть від них словосполучення, складні за будовою. 
Враження до пісні, навчатися музиці, навчає правді, навчання на французькій мові, докоряти учня, дякувати Павла, заперечувати проти думки, додержуватися тиші.

VI. Утворіть словосполучення за поданими схемами. Визначте головне та залежне слова.

1) дієслово + іменник у давальному відмінку з прийменником;

2) займенник + іменник;

3) дієслово + займенник;

4) прикметник + іменник у родовому відмінку з прийменником;

5) дієслово + іменник у родовому відмінку з прийменником.

Самостійна робота студента є основним засобом оволодіння навчальним матеріалом у час, вільний від обов'язкових навчальних занять. Вона $\epsilon$ завершальним етапом засвоєння навчального матеріалу, який розглядався на лекціях, практичних і лабораторних заняттях. Самостійна робота привчає студентів до ініціативності та дисциплінованості, виховує відповідальність та позитивні мотиви майбутньої професійної діяльності. Для активізації самостійної роботи майбутніх фахівців було рекомендовано такі прийоми:

- $\quad$ чітко визначати та доводити до відома студентів зміст самостійної роботи, етапи і терміни її виконання, форми звітності, критерії оцінювання;

- розробляти графіки самостійної роботи, які допомагають студенту раціонально використовувати час, а викладачу - забезпечити систематичний контроль і своєчасну допомогу під час засвоєння нового матеріалу, його закріплення і застосування;

- застосовувати методи активного навчання (аналіз конкретних ситуацій, дискусія, групова і парна робота, проблемне навчання, колективне обговорення питань, ділові ігри тощо);

- $\quad$ використовувати професійно орієнтовані завдання, які розкривають роль і значення конкретного навчального матеріалу в становленні професійної майстерності студентів (добір додаткового матеріалу 3 теми, анотування професійної та наукової літератури тощо);

розроблення комплексних електронних навчальних посібників для самостійної роботи, що вміщують основний теоретичний матеріал з дисципліни (тезовий конспект лекцій), методичні вказівки до практичних занять, перелік завдань для самостійної роботи, теми доповідей, рефератів, курсових, дипломних, кваліфікаційних робіт, списки обов'язкової і додаткової літератури, питання до іспитів тощо.

Висновки. Педагогічна професія висуває перед майбутнім фахівцем цілу низку вимог: до якостей особистості, до загального інтелектуального рівня розвитку, до рівня спеціально-професійних знань, умінь і навичок. Інноваційні підходи у виборі форм і методів навчання, реформування освіти на всіх рівнях, перебудова вищої школи в руслі Болонської угоди створюють умови для якісної підготовки майбутніх фахівців. Застосування методу моделювання в 
Педагогічне моделювання як засіб формування методичної компетентності вчителя

педагогічній діяльності сприяє підвищенню якості освіти, готує молодь до практичної професійної діяльності в сучасних умовах, розуміння загальної схеми формування змісту навчання, цілей освітньої та професійної підготовки, розподілу змісту циклів підготовки за навчальними дисциплінами, визначення рівня сформованості предметних умінь, структури та змісту програми навчальної дисципліни; висвітлення принципів побудови моделі освітньої та професійної підготовки фахівця, а також використання цих знань в якості теоретичної основи загальної схеми формування змісту навчання. Ці знання сприятимуть успішному здійсненню випускниками ефективної педагогічної діяльності в загальноосвітнього навчального закладу.

\section{СПИСОК ВИКОРИСТАНИХ ДЖЕРЕЛ}

1. Закон України про вищу освіту. № 1556-18. (2014, 1 липня). Взято 3 http://zakon2.rada.gov.ua/laws/show/1556-18

2. Кушнір, В. А. (2003). Теоретико-методологічні основи системного аналізу педагогічного процесу вищої школи : дис. ... д-ра пед. наук Ін-т педагогіки і психології професійної освіти АПН України, - Київ.

3. Лодатко, Є. О. (2010). Моделювання в педагогіці: точки відліку. Педагогічна наука: історія, теорія, практика, тендениії розвитку, № 1. [Електроний ресурс] Режим доступу: http://intellect-invest.org.ua/pedagog_editions_e-magazine_pedagogical_science_vypuski_n1_2010_st_2/

4. Марчій-Дмитраш, Т. М. (2012). Ігрове моделювання у процесі підготовки майбутніх учителів початкової школи. Педагогічний дискурс, 13, 216 - 219.

5. Цимбалару, А. Д. (2007). Педагогічне моделювання. Науковий часопис НПУ імені М. П. Драгоманова, Bun. 6, $196-199$.

\section{ПЕДАГОГИЧЕСКОЕ МОДЕЛИРОВАНИЯ КАК СРЕДСТВО ФОРМИРОВАНИЯ МЕТОДИЧЕСКОЙ КОМПЕТЕНТНОСТИ БУДУЩЕГО УЧИТЕЛЯ}

\section{Елена Ишутина}

кандидат педагогических наук, доцент кафедры теории и практики начального образования

ГВУЗ «Донбасский государственный педагогический университет»

г. Славянск, Украина

http://orcid.org/0000-0002-7801-4205

olenaishutina@gmail.com

Елизавета Шаповалова

студентка факультета начального, технологического и

профессионального образования

ГВУЗ «Донбасский государственный педагогический университет»

г. Славянск, Украина

yeshapovalova@gmail.com

Аннотация. В статье представлен общий анализ педагогического моделирования как средства формирования методической компетентности будущего учителя, раскрыты некоторые подходы к классификации, представлены основные позиции применения 
Педагогічне моделювання як засіб формування методичної компетентності вчителя

педагогического моделирования в теории и практике профессионального образования учителей. Доказано, что любое моделирование предусматривает использование абстрагирования и идеализации (особенно это относится к моделированию сложных педагогических систем, поведение которых зависит от большого числа взаимосвязанных факторов различной природы). В педагогическом моделировании чаще всего востребованы структурно-функциональные модели, при проектировании которых объект рассматривается как целостная система, включающая составные части, компоненты, элементы, подсистемы. Построение такой модели позволяет получить новую информацию о поведении объекта, выявить взаимосвязи и закономерности, которые не удается обнаружить при других способах анализа. Студентам предлагалось строить модели макро- и микроструктуры аспектных уроков и уроков связной речи в разных классах. Моделируя уроки языка, будущие учителя пользовались усвоенными на занятиях по педагогике, психологии и лингвометодики лингвометодическими терминами-синонимами.

Ключевые слова: высшее образование; методическая компетентность; моделирование; педагогическое моделирование; учитель начальной школы.

\title{
PEDAGOGICAL MODELLING AS A MEANS OF FORMING PROSPECTIVE TEACHER'S METHODOLOGICAL COMPETENCE
}

\author{
Olena Ishutina \\ Candidate of Pedagogical Sciences, \\ Associate Professor of Primary Education Theory and Practice Department, \\ State Higher Educational Establishment "Donbas State Pedagogical University" \\ Sloviansk, Donetsk region, Ukraine \\ http://orcid.org/0000-0002-7801-4205 \\ olenaishutina@gmail.com \\ Yelyzaveta Shapovalova \\ Student of the Faculty of Primary, Technological and Vocational Education, \\ State Higher Educational Establishment "Donbas State Pedagogical University" \\ Sloviansk, Donetsk region, Ukraine \\ yeshapovalova@gmail.com
}

\begin{abstract}
The article presents a general analysis of pedagogical modelling as a means of forming future teachers' methodological competence, some approaches to classification are disclosed, basic positions of the application of pedagogical modelling in the theory and practice of vocational education of teachers are presented. It is proved that each modelling involves using abstraction and idealization (especially this applies to the modelling of complex pedagogical systems whose behavior depends on a large number of interrelated factors of a different nature). In pedagogical modeling, structural and functional models are most often in demand, when designing which the object is considered as an integral system, including component parts, components, elements, subsystems. The construction of such a model allows to obtain new information about the behavior of the object, to reveal interrelations and patterns that cannot be detected with other methods of analysis.

The authors consider modelling of linguomethodological activity as a specific method of control, which allows the teacher to assess the level of linguomethodological literacy of students, their ability to use knowledge to solve specific methodological problems creatively, the mastering of basic linguomethodological skills. Students were asked to build models of macro- and microstructure of the aspect lessons and lessons of coherent speech development in different classes. Modelling the
\end{abstract}

Професіоналізм педагога: теоретичні й методичні аспекти. - Вип. 7. - Слов’янськ, 2018. 
lessons of the language, future teachers used some linguomethodological terms and their synonyms learned in pedagogy, psychology and linguistic methodology.

The authors note that independent work of the student is the main means of mastering the educational material at the time, free of compulsory training. It is the final stage of mastering the educational material, which was considered at lectures, practical and laboratory classes, and pedagogical modelling is one of its important parts.

Key words: higher education; methodological competence; modelling; pedagogical modelling; a primary school teacher.

\section{REFERENCES}

1. Law of Ukraine on Higher Education. № 1556-18. (2014, July 1). Retrieved from http://zakon2.rada.gov.ua/laws/show/1556-18

2. Kushnir, V. A. (2003). Theoretical and methodological foundations of systemic analyses of the higher school educational process. Doctor's thesis. Kyiv: In-t of pedagogy and psychology of vocational education of APS of Ukraine.

3. Lodatko, Ye. O. (2010). Modelling in pedagogy: reference points. Pedahohichna nauka: istoriia, teoriia, praktyka, tendentsii rozvytku, № 1. Retrieved from: http://intellectinvest.org.ua/pedagog_editions_e-magazine_pedagogical_science_vypuski_n1_2010_st_2/

4. Marchii-Dmytrash, T. M. (2012). Gaming modelling in the process of training future primary school teachers. Pedahohichnyi dyskurs, 13, 216-219.

5. Tsymbalaru, A. D. (2007). Pedagogical modelling. Naukovyi chasopys NPU imeni M. P. Drahomanova, Vyp. 6, $196-199$.

Матеріали надійшли до редакції 23.04.2018 p. 